\title{
PROVENANCE OF ZIRCON OF THE LOWERMOST SEDIMENTARY COVER, ESTONIA, EAST-EUROPEAN CRATON
}

\author{
MARE KONSA AND VÄINO PUURA
}

KONSA, MARE and PUURA, VÄINÖ 1999. Provenance of zircon of the lowermost sedimentary cover, Estonia, East-European Craton. Bulletin of the Geological Society of Finland, Number 71, Part 2, 253-273.

Bulk and accessory mineral composition of fresh and weathered crystalline rocks, and sedimentary deposits overlying the crystalline-sedimentary unconformity have been examined in core samples from 28 drill holes in Estonia. Before the Late Vendian to Early Cambrian regional subsidence and sedimentation, the region represented a flat plateau within the Svecofennian Domain. Palaeo- and Mesoproterozoic crystalline rocks, regardless their different initial mineral composition, subcrop under the Upper Vendian/Lower Cambrian sedimentary cover as usually intensely weathered rocks (saprolites) composed of residual quartz, altered micas and prevailing clay minerals mainly of the kaolinite group. Thus, the bulk mineral composition of any basement crystalline rocks imparts no specific inherited rock-forming minerals into the covering sedimentary rocks.

From the variety of accessory and opaque minerals of crystalline rocks, only zircon populations survived in saprolites. Crystalline rocks of different origin yield different zircons. Relationships between the zircon typology of the basement rocks having specific areas of distribution and the sedimentary rocks immediately overlying those crystalline rocks were the main subject of this study. The result is that siliciclastic sedimentary rocks covering weathered crystalline rocks only in places inherited zircons with typological features characteristic of specific basement areas. In northeastern Estonia, local lenses of the Oru Member (the earliest Upper Vendian sedimentary rocks in Estonia resembling the debris of weathered crystalline rocks) yield accessory zircon which in a 1-2 m thick layer above the basement surface is similar to the zircons of the underlying weathering mantle of certain crystalline rocks. In the next unit, the Moldova Member, up to $43 \mathrm{~m}$ above the basement surface, a mixture of zircons resembling those of various local basement rocks has been found.

Further upwards, in the Vendian and Lower Cambrian sequence, zircons resembling those of local basement sources are very rare or absent. Obviously, basal Vendian/Cambrian sedimentary rocks sealed off the basement as a source of zircon. Therefore a distant source, probably outside the Svecofennian Domain, could be supposed for the bulk clastic minerals and zircons of the upper part of the Vendian and the lower part of the Cambrian. Probably, studies of isotopic ages of different typological varieties of zircons, both of obviously local and distant origin, could provide new information on respective source rock ages and areas, and on the general palaeogeographic pattern of the Vendian and Cambrian epicratonic sedimentary basins of the East-European Craton. 
Key words: sedimentary rocks, zircon, provenance, crystalline rocks, basement, Cambrian, Proterozoic, Estonia

Mare Konsa: Institute of Geology, 10143 Tallinn, Estonia

Väino Puura: Institute of Geology, 10143 Tallinn, Estonia; Institute of Geology, University of Tartu, Vanemuise 46, 51014 Tartu, Estonia

E-mail:puura@ut.ee

\section{INTRODUCTION}

The unique geology of Estonia provides an opportunity to study a most prominent geological discontinuity in a sequence of old continental crust with transition between the Precambrian highgrade crystalline basement and the overlying unmetamorphosed sedimentary cover. In the northwestern part (or the Fennoscandia crustal segment, e.g. Gorbatschev \& Bogdanova 1993) of the EastEuropean Craton, along the southern periphery of the Fennoscandian Shield, the crystalline/sedimentary transition is a most prominent unconformity. Estonia is located in the central part of the Svecofennian Domain (when the extensions of Svecofennian bedrock beneath the late Proterozoic and Phanerozoic sedimentary rocks to eastern Poland and western Ukraine are taken into account).

During the 1.9-1.8 Ga Svecofennian orogeny and folded mountain building and during the 1.65$1.50 \mathrm{Ga}$ extensive anorogenic rapakivi magmatism, coupled with volcano-plutonic centres and block mountain building, very rapid erosion exposed deep horizons of the upper crust (Puura \& Flodén 1999). Afterwards, during a more than 1 billion year-long continental period in the Mesoand Neoproterozoic, gentle erosion and planation dominated in the Svecofennian Domain. Prior to the onset of the late Proterozoic and Phanerozoic sedimentation, the main discontinuity surface represented an almost perfect horizontal plain. Local erosional remnants - monadknocks - were very rare, and negative landforms, such as valleys, did not exist (Puura et al. 1983). The uppermost part of the crystalline basement was weathered, and the weathering profile is well preserved. In drill cores, the erosion-related waste mantle has been recognised only locally at the crystalline basement sedimentary cover transition.
The large transgression, which started the formation of the sedimentary cover of the East-European Craton, was initiated by subsidence along the Central Russian Aulacogen in the Neoproterozoic (Nikishin et al. 1996). The Svecofennian Domain is located in the SW flank of the aulacogen that follows the boundary between the Fennoscandia and Volgo-Uralia segments of the EastEuropean Craton (Bogdanova et al. 1996). This domain was not substantially fragmented through the Meso- and Neoproterozoic rifting of the Craton.

In the Late Vendian (latest Neoproterozoic) and Cambrian, the eastern part of the Svecofennian Domain and the whole of the Fennoscandia crustal segment subsided. Consequently, the gradual transgression of the basin from the east to the west corresponded to the regional epeirogenic movements within the Svecofennian Domain. The regional clastic sediment supply from the southwest and west to the central East-European Craton became stable, as it was recorded in the facies zonation of the past basins: sandstones in the west, siltstones in the middle and claystones in the east (e.g. Rozanov \& Lydka 1987). In the Late Vendian and Early Cambrian, the transgression from the east and northeast reached the territory of Estonia. Transgressive clastic sediments covered the weathering zone. The thickness of the basal coarse-grained sedimentary rocks seldom exceeds $10 \mathrm{~cm}$. Both the preserved weathering profile and the small thickness of the coarse-grained basal sedimentary rocks are evidence of the poor erosion of the pre-sedimentary peneplain in the course of the transgression that started the formation of the mainly Phanerozoic sedimentary cover.

A still unresolved significant problem in the region concerns the source of clastic sediments during the Late Vendian and Cambrian when the 
early platform cover was formed. The complete weathering profile was preserved even in the western part of the East-European Craton, which finally became covered with Cambrian sedimentary rocks. This is evidence of the low intensity of late Neoproterozoic to early Cambrian erosion, which ended the long continental period within the craton area. Thus, it can be assumed that huge amounts of clastic material that composed the Vendian and Cambrian sequences were transported into the region from the western periphery of the Svecofennian Domain. Considering the facies zonation, one of the source areas was located west of that domain. So far, the problem of the sediment sources outside the Svecofennian Domain has not been studied.

Our attempt to find inherited relationships between either the local basement rocks or sources outside the Svecofennian Domain, on the one hand, and the basal layers of the sedimentary cover, on the other, was favoured by the excellent preservation of the original mineral composition of the clastic compounds in the basal sedimentary rocks of the cover. In some other regions, subsequent subsurface alteration processes have affected less resistant minerals of the weathering profile and basal sedimentary layers (Sutton \& Maynard 1996). However, this is not the case in Estonia where the role of post-sedimentary clastic mineral changes was negligible.

Thus, in a given area, participation of the source material eroded from the surface of the local basement remains a problem which needs special consideration. As shown by Pupin (1980) and Byksteeg et al. (1995), crystalline rocks of different origin yield different types of zircons. In order to estimate the volume of the basal sedimentary rocks affected by the local source of clastic material we examined the mineralogies in: (1) the fresh crystalline rocks of the basement, (2) the weathering profile covering the fresh basement rocks, and (3) the basal layers of the overlying Upper Vendian and Lower Cambrian sedimentary rocks. We will attempt to estimate the role of both local and distant sources in the formation of the basal layers of the sedimentary cover using mineralogical criteria.

\section{FIELD AND LABORATORY TECHNIQUES}

Our project was initiated in 1970 and included mineralogical studies of the crystalline rocks of the basement. At the same time, the lithologies of these rocks (Puura et al. 1983, Klein et al. 1994), the mineralogies of weathering profiles (Kuuspalu et al. 1971, Puura et al. 1983), and the lithologies of Vendian and Cambrian deposits (Mens \& Pirrus 1986) have been studied. The results of these investigations are used as background information for the present project.

Subsurface geological mapping was necessary to get data on the main unconformity between the crystalline basement and sedimentary cover. In the 1960 s through the 1980 s, the mapping programs applied geophysical methods and drilling (Koistinen 1994, 1996). During the present project, 28 drill cores intersecting the crystalline basement sedimentary cover transition were examined (Table 1). They represent different lithologies of the basement. At least one drill core sequence for each rock type described below was studied to characterise mineral composition and zircon typology (see Fig. 1 for locations). Also, different age zones of the basal layers of the sedimentary cover, ranging from the Late Vendian to the uppermost Early Cambrian, were studied (Table 2, Figs. 2a and b).

The distribution of major silicate and accessory minerals in the basement, their alteration in the weathering profile, and their specific assemblages in the basal sedimentary strata (Fig. 3) were examined by means of immersion-microscopic analyses, using also published results of thin section and XRD studies.

Fifty-seven samples of different varieties of crystalline rocks, 50 samples from weathering profiles and 145 samples from the lower part of the Vendian-Cambrian clastic sedimentary sequences were studied by crystallo-optical techniques (Table 1). The samples were crushed and washed, and heavy minerals were separated using bromoform. Zircon typologies were investigated in immersion with the grain size of $0.1-0.05 \mathrm{~mm}$ considered in this paper as coarse-grained silt. Each sample contained 400-500 (in the case of a low content not less than 200) zircon grains. 
Table 1. Samples studied in immersion.

\begin{tabular}{|c|c|c|c|c|c|}
\hline \multicolumn{6}{|c|}{ SAMPLES FROM THE SEDIMENTARY ROCKS } \\
\hline $\begin{array}{c}\text { Sub- } \\
\text { system }\end{array}$ & \multicolumn{3}{|c|}{$\begin{array}{l}\text { Lithostratigraphic units (Indices see Fig } \\
\text { 2) }\end{array}$} & $\begin{array}{c}\text { Number of } \\
\text { samples }\end{array}$ & Cores sampled (for location see Fig. 1) \\
\hline \multirow{2}{*}{ 茎这 } & \multicolumn{3}{|c|}{$\begin{array}{l}\text { Soela Formation }\left(\epsilon_{1} s l\right) \text { lying on } \\
\text { Mesoproterozoic rapakivi granites }\end{array}$} & 1 & 500 \\
\hline & \multicolumn{3}{|c|}{$\begin{array}{l}\text { Voosi Formation }\left(\epsilon_{1} v s\right) \text { lying on two- } \\
\text { pyroxene gneisses }\end{array}$} & 2 & 173 \\
\hline \multirow{8}{*}{ 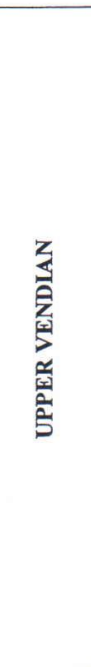 } & \multicolumn{3}{|c|}{ Voronka Formation $\left(\mathbf{V}_{2} \mathbf{v r}\right)$} & 28 & $\begin{array}{l}\text { F129, F144, F147, F150, F154, F155, F156, } \\
\text { F161, F169, F195, F198, F199 }\end{array}$ \\
\hline & \multicolumn{3}{|c|}{ Kotlin Formation $\left(\mathbf{V}_{2} \mathrm{kt}\right)$} & 13 & $\begin{array}{l}\text { F144, F154, F155, F156, F159, F169, F195, } \\
\text { F198, F199 }\end{array}$ \\
\hline & \multirow{6}{*}{ 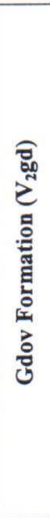 } & \multicolumn{2}{|c|}{ Uusküla Member $\left(V_{2} g d U\right)$} & 53 & $\begin{array}{l}\text { F136, F144, F146, F149, F150, F152, F153, } \\
\text { F154, F155, F156, F159, F161, F163, F164, } \\
\text { F168, F169, F195, F199 }\end{array}$ \\
\hline & & \multirow{2}{*}{$\begin{array}{l}\text { Moldova } \\
\text { Member } \\
\left(\mathbf{V}_{2} \text { gdM) }\right.\end{array}$} & $\begin{array}{l}\text { Lying on Oru } \\
\text { Member }\end{array}$ & 7 & F144, F159, F169, F198 \\
\hline & & & Lying on basement & 26 & $\begin{array}{l}\text { F129, F136, F146, F147, F149, F150, F152, } \\
\text { F156, F163, F164, F195, F199 }\end{array}$ \\
\hline & & \multirow{3}{*}{$\begin{array}{l}\text { Oru } \\
\text { Member } \\
\left(V_{2} \text { gdO }\right)\end{array}$} & $\begin{array}{l}\text { Lying on Al-rich } \\
\text { and Bi gneisses }\end{array}$ & 8 & F144, F153, F169, F189, F190 \\
\hline & & & $\begin{array}{l}\text { Lying on Bi-Amph } \\
\text { and } B i \\
\text { plagiogneisses }\end{array}$ & 2 & F159 \\
\hline & & & $\begin{array}{l}\text { Lying on granite } \\
\text { gneisses and } \\
\text { charnockites- } \\
\text { enderbites }\end{array}$ & 5 & 423,555 \\
\hline
\end{tabular}

\begin{tabular}{|c|c|c|c|c|}
\hline \multicolumn{5}{|c|}{$\begin{array}{l}\text { SAMPLES FROM THE CRYSTALLINE BASEMENT ROCKS } \\
\text { (F - fresh, } \mathrm{W} \text { - weathered, indices of minerals see Fig. } 4 \text { ) }\end{array}$} \\
\hline \multirow{2}{*}{\multicolumn{2}{|c|}{ Rock type }} & \multicolumn{2}{|c|}{ Number of samples } & \multirow{2}{*}{ Cores sampled } \\
\hline & & $\mathbf{F}$ & $\mathbf{W}$ & \\
\hline MESO & PROTEROZOIC rapakivi granite & 1 & 2 & 500 \\
\hline \multirow{11}{*}{ 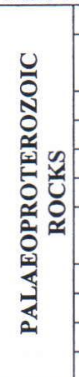 } & Porphyritic rapakivi granite & 2 & 2 & F508 \\
\hline & $\begin{array}{l}\text { Bi-Amph-Px and two-pyroxene } \\
\text { gneiss }\end{array}$ & 2 & 1 & 173 \\
\hline & Granite gneiss & 2 & 3 & 423,555 \\
\hline & Bi-Amph gneiss & 5 & 5 & F159, F153, F169 \\
\hline & Amphibolite & 2 & 1 & F147 \\
\hline & Bi plagiogneiss & 1 & 2 & $\begin{array}{r}\text { F129 } \\
\end{array}$ \\
\hline & $\mathrm{Al}$-rich gneiss and $\mathrm{Bi}$ gneiss & 28 & 24 & $\begin{array}{l}\text { F144, F146, F147, F149, F150, F152, F154, } \\
\text { F155, F156, F187, F190, F198, F199 }\end{array}$ \\
\hline & Charnockite-enderbite & 2 & 1 & 555 \\
\hline & Granite-migmatite & 6 & 4 & F169, F164, F195 \\
\hline & Plagiogranite & 2 & 1 & F163 \\
\hline & Pl-Mi granite & 4 & 4 & F161, F168 \\
\hline
\end{tabular}

Zircons from the fresh crystalline rocks, the weathering profiles, and from the clastic sedimentary rocks - siltstones and sandstones - were compared. Relationships between composition of the crystalline rocks and zircon morphologies were distinguished in order to follow their features through the weathering profile and the basal sedimentary layers. As described in the following chapters, within a large variety of zircon types only a part of them show features which are considered to be informative for our study (Viiding 1976, Viiding \& Konsa 1976). Thus, after the distribution of specific varieties of zircon in the rocks was outlined, some distinct crystalline and sedimentary rocks were selected for detailed sampling and using zircon typologies in source rock search. 


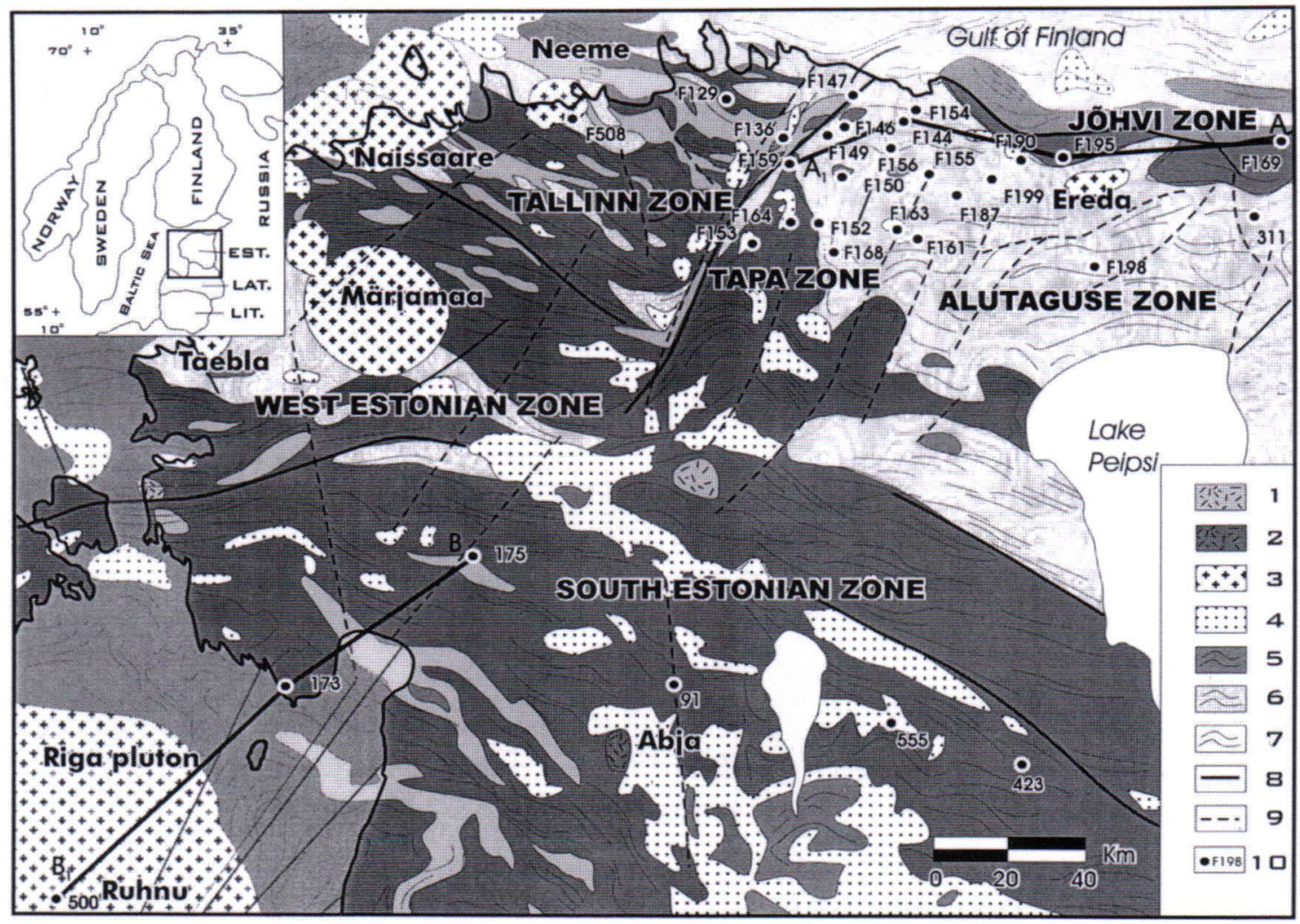

Fig. 1. Basement lithologies and structure after Koistinen (1994) and locations of the drill cores studied. 1. Intermediate plutonic rocks; 2. Gabbro; 3. Anorogenic rapakivi granites and related rocks; 4. Granites; 5. Mafic and intermediate metavolcanic rocks with strike; 6. Mica schists and mica gneisses with strike; 7. Felsic metasedimentary and metavolcanic rocks with strike; 8. Proterozoic faults; 9. Phanerozoic faults in the basement and sedimentary cover; 10. Drill holes penetrating into the basement. $A-A_{1}$ and $B-B_{1}$ are cross sections of Fig. 2. In the index map: EST. - Estonia, LAT. - Latvia, LIT. - Lithuania.

\section{COMPOSITION OF THE CRYSTALLINE SUITES OF THE BASEMENT}

The crystalline basement of Estonia (Fig. 1) is composed mainly of a large variety of high-grade metamorphic and plutonic rocks with an age of between 1.9 and 1.5 Ga (Puura \& Huhma 1993, Rämö et al. 1996). Early orogenic, metamorphosed rocks of primary sedimentary and felsic to mafic volcanic origin form the framework of the basement. Late orogenic granitoids and anorogenic rapakivi granites are also quite abundant.

Based on bulk mineral composition (Fig. 3) and distribution of typological varieties of zircon (Klein \& Konsa 1986; Fig. 4), the orogenic crys- talline rocks are herein subdivided into three groups:

(1) Biotite- and amphibole-bearing gneisses, amphibolites and metagabbros occur as narrow folded belts in the Tallinn and Alutaguse zones, and in northwestern Estonia. Pyroxene-bearing rocks are abundant in the orogenic complex of southern Estonia and occur also in the Jõhvi and Tapa zones of northern and northeastern Estonia. This rock group mainly comprises intermediate and mafic gneisses and amphibolites consisting of plagioclase, hornblende and biotite. K-feldspar and orthopyroxene occur in gneisses, which were subjected to granulite metamorphism and charnockite injection. A small amount of quartz is associ- 
Table 2. Stratigraphy of Upper Vendian and Lower Cambrian deposits in Estonia. Simplified after Mens and Pirrus (1997).

CAMBRIAN

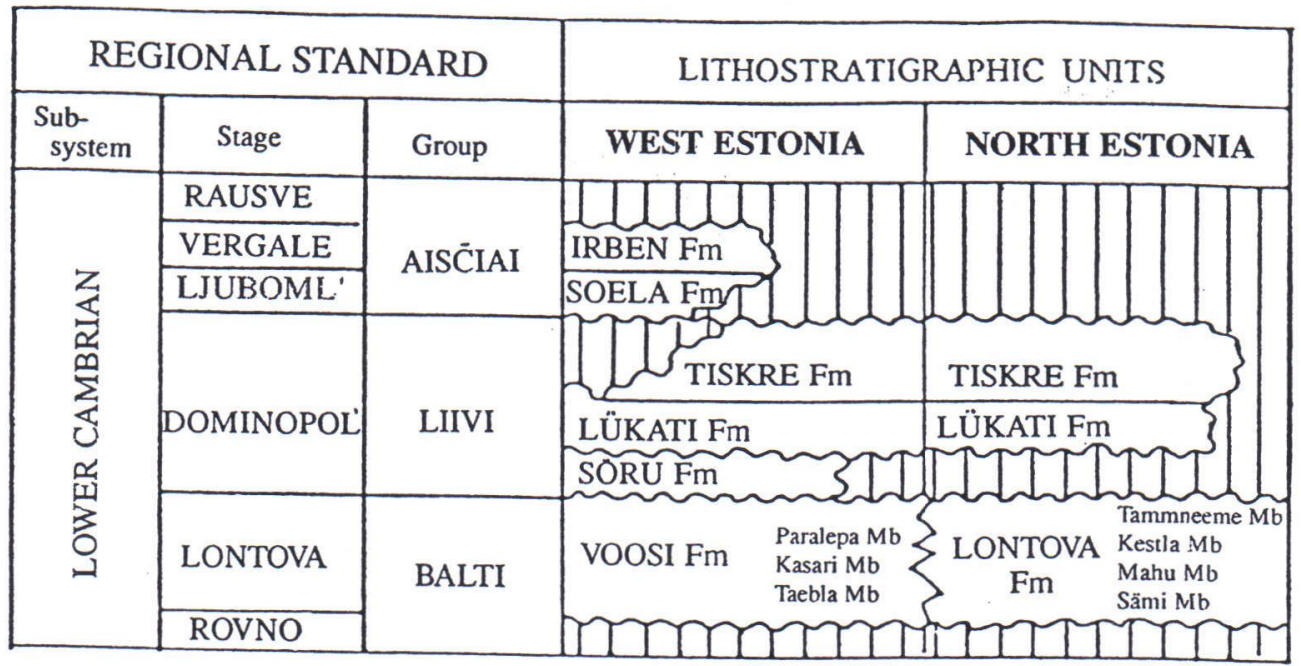

VENDIAN

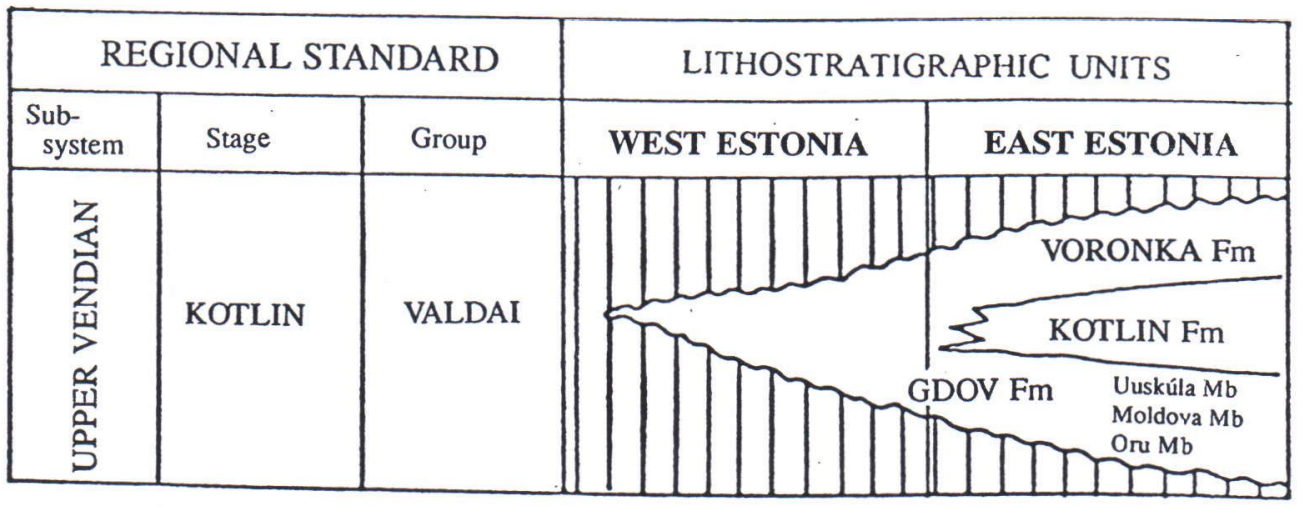

ated with K-feldspar. Magnetite, pyrrhotite, pyrite and ilmenite represent ore minerals. Accessory minerals include apatite, which often predominates, and zircon, monazite, garnet and titanite.

(2) Aluminium-rich gneisses, frequently alternating with biotite gneisses, prevail in the Alutaguse zone and occur also in the Tallinn zone. Alrich gneisses contain abundant Al-minerals (cordierite, sillimanite, garnet, muscovite, and rare andalusite). Some layers contain graphite. Apatite, zircon, and monazite represent accessory miner- als, and tourmaline and spinel are rare. Ore minerals include pyrrhotite, pyrite, magnetite and ilmenite; sphalerite is less frequent. Mica gneisses consist mostly of quartz, plagioclase and biotite, accompanied by cordierite, sillimanite, garnet and graphite.

(3) Quartz-feldspar and granite gneisses are common in the Tallinn zone. In the quartz-feldspar gneisses up to $90 \%$ of the rock consists of quartz, plagioclase and K-feldspar, biotite also occurs frequently, whereas muscovite and garnet 

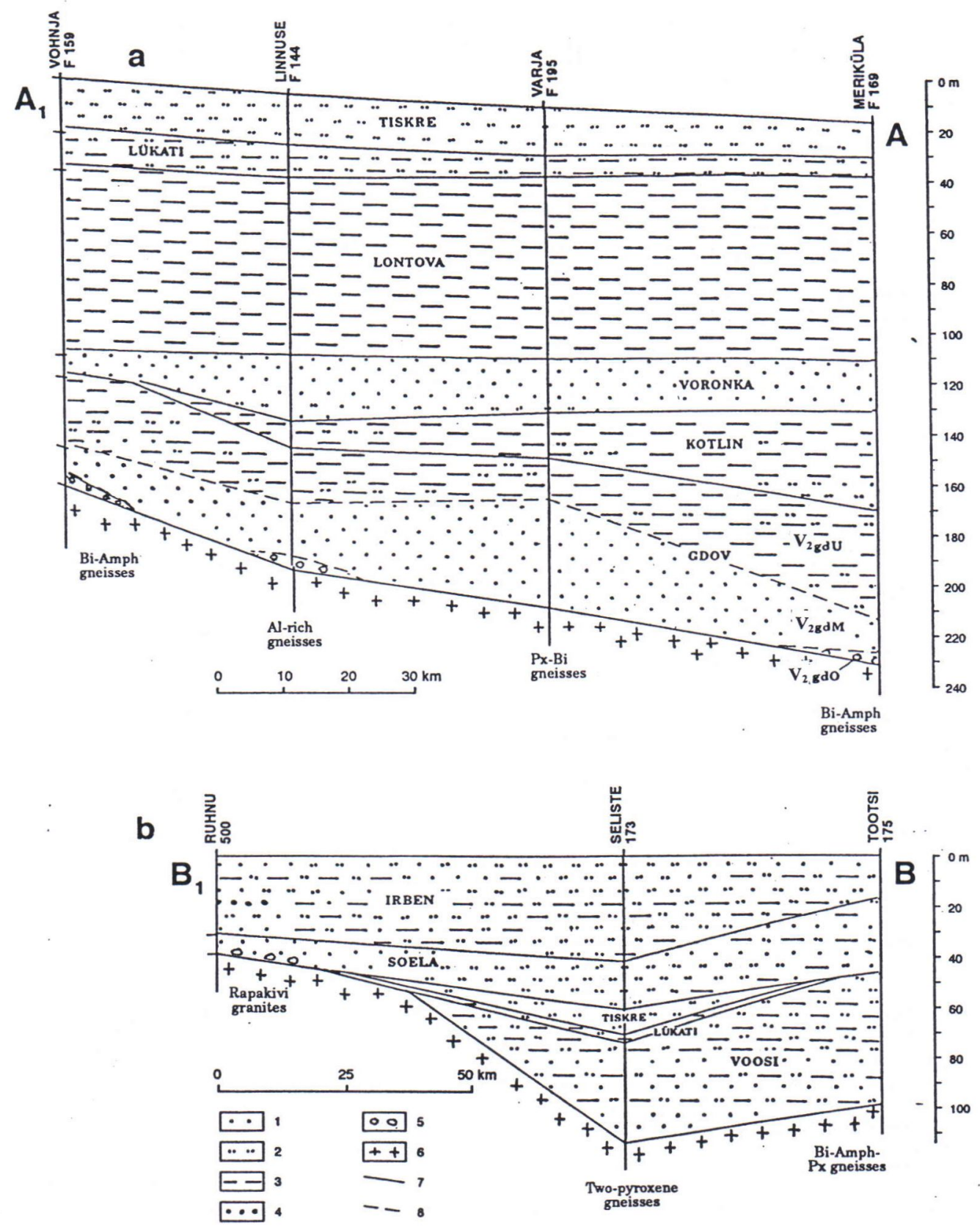

Fig. 2. Cross section of the Vendian-Cambrian part of the sedimentary cover in Estonia and the generalized stratigraphic position of the layers studied in core sections. Lithologies: 1. sandstone; 2. siltstone; 3. claystone; $2+3$. intercalating layers of siltstone and claystone; 4. pebbles; 5. mixtites (mixes of gravelly to clayey deposits); 6. crystalline rocks of the basement; 7. boundary of formations; 8. boundary of members. $V_{2} g d O=$ Oru Member of the Vendian Gdov Formation, $V_{2} g d M=$ Moldova Member of the Vendian Gdov Formation, $V_{2} g d U=U$ usküla Member of the Vendian Gdov Formation.

a. profile $A-A_{1}$ (see Fig. 1); b. profile $B-B_{1}$ (see Fig. 1). 


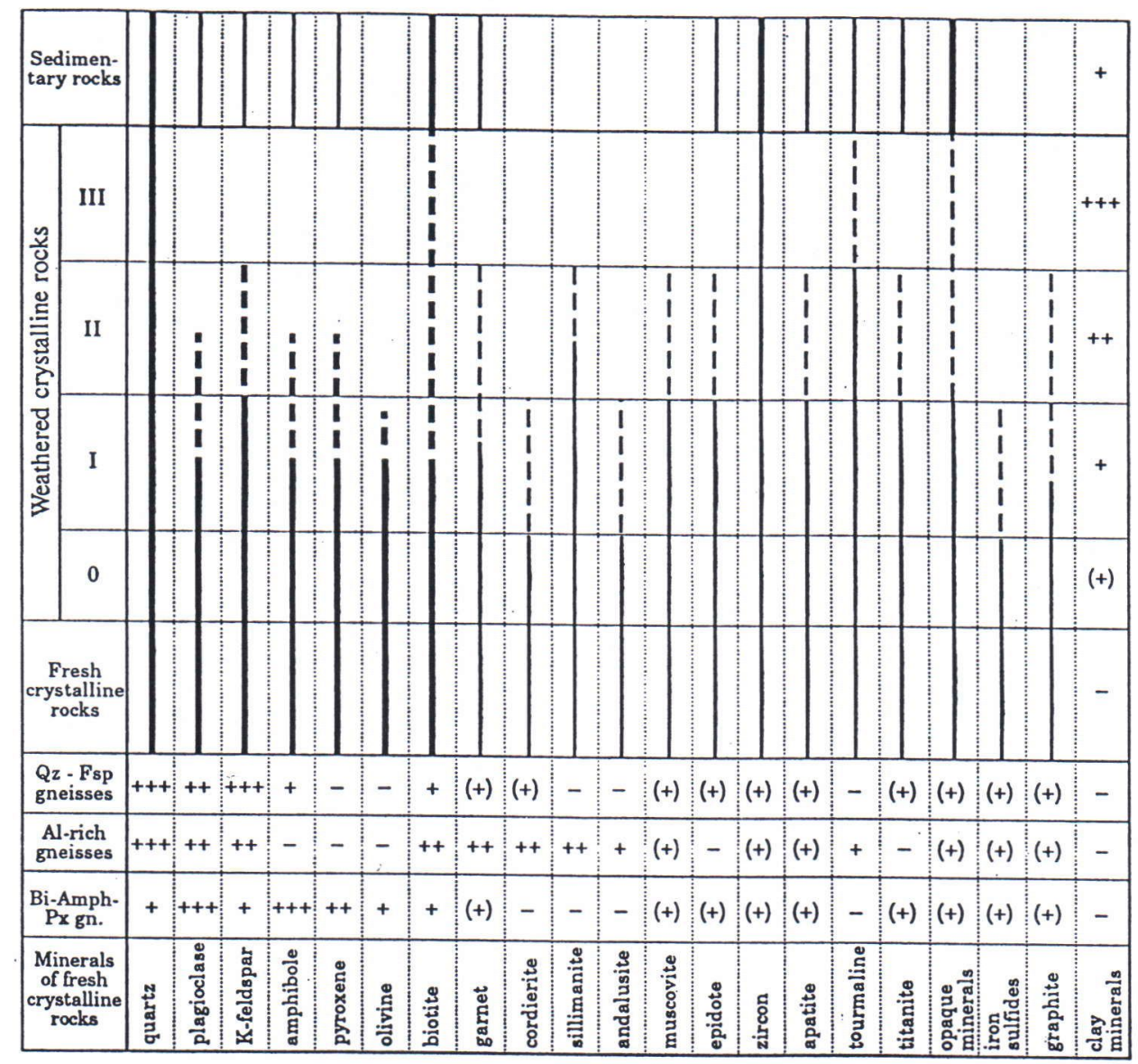

$\mathrm{Qz}$ - quartz, Fsp - feldspar, Bi - biotite, Amph - amphibole, Px - pyroxene

Fig. 3. Distribution of major and minor minerals in the studied fresh and weathered crystalline rocks and sedimentary rocks. Abundance of minerals in the crystalline rocks and abundance of clay minerals in the sedimentary cover: +++ most abundant, ++ abundant, + usually present, $(+)$ occasional minor component.

are sporadical. Magnetite, pyrrhotite and pyrite represent ore minerals. The most common accessory minerals are apatite, zircon and sphene.

In contrast to the patchy alternation of rock types in the orogenic belts, the anorogenic rapakivi plutons and batholiths (Fig. 1) form large areas of considerably constant composition. The largest of them, the Riga rapakivi batholith, makes up the basement of the Gulf of Riga, the central Baltic Sea and western Latvia. The contents of accessory and ore minerals in both large and minor rapakivi occurrences are high. In the large batholiths Ti-bearing magnetite, titanite, apatite, zircon, and fluorite are most abundant (Bogatikov \& Birkis 1973, Kuuspalu 1975). In the other main type of rapakivi occurrences - porphyritic microcline granite plutons (e.g. Märjamaa, Naissaar, Neeme, Ereda; Fig. 1) - the content of various accessory minerals is characteristic for every particular pluton and, especially, the igneous phases within them (Klein et al. 1994).

The areas of specific zircon-bearing crystalline rocks can be used for the interpretation of the inheritance of the mineral composition of the sedimentary cover from the local basement source. 


\section{WEATHERING OF THE CRYSTALLINE SUITES AND PRESERVATION OF ZIRCON}

In the weathering profile of the studied rocks, up to four stages can be distinguished (Fig. 3). However, the levels of different weathering intensity are usually discontinuous, most of all depending on fracture zones. The weathering front is usually highly transitional in character. In our classification of weathered rocks (stages 0-III; Kuuspalu et al. 1971), stage 0 marks the minor partial alteration of the most unstable minerals like plagioclase, hypersthene and other dark-coloured minerals in a hard rock. At stage I, most dark minerals and up to $50 \%$ of feldspars have been altered. At stage II, in soft rocks, silicates and other unstable minerals are represented by clay pseudomorphs, although the primary textures and structures can still be recognised. Rocks of weathering stage III are loose aggregates of clay minerals, with remnant grains of quartz and accessory zircon. The original texture has disappeared, and the original structures have been replaced by horizontal undulating pseudolayering due to the distribution of iron minerals. The rocks of weathering stage III are typical saprolite.

The mature weathered rocks immediately underlying the sedimentary cover are mainly composed of kaolinite, but also contain illite, chlorite, montmorillonite-chlorite and montmorillonite. In detail, the mineral composition of the weathering profile depends on the primary rock composition and the intensity of alteration (Kuuspalu et al. 1971, Puura et al. 1983). In the weathering profile of mafic rocks, zonality of clay minerals is, from the bottom to the top: montmorillonite, illite-montmorillonite-chlorite, kaolinite-montmorillonite-illite, and kaolinite. In profiles composed of intermediate and Al-rich rocks, the sequence of clay mineral zones is: montmorillonite-chlorite, kaolinite-montmorillonite-illite, and kaolinite. On felsic rocks, the weathering mantle comprises the following zones: illite-chlorite, illite-kaolinite, and kaolinite. The weathering has stopped everywhere at the stage of kaolinite prevalence, and quartz and zircon have survived. Therefore, at the weathered basement - sedimentary cover contact often only zircon carries information on the primary composition of the crystalline rocks subjected to weathering. No bauxite minerals were documented by XRD.

To sum up, to study the problems of inheritance of clastic sedimentary rocks from the Precambrian basement, the primary lithologies and bulk mineral composition of unweathered rocks are not highly informative in areas where the primary weathering profile has not been severely eroded. Areas of erosion of the weathering profile are not well developed in the study area. If there is any important inherited feature in the composition of the basal beds from the underlying basement, the most important source rocks should be at the stage of intensive weathering. Thus, we shall next examine zircon - the stable and typologically considerably variable mineral surviving up to the top of the weathering profile, and resistent in the sedimentary rocks.

\section{MAIN TYPOLOGICAL VARIETIES OF ZIRCON IN FRESH AND WEATHERED PRECAMBRIAN CRYSTALLINE ROCKS}

We studied zircon typologies separately in groups of crystalline orogenic and anorogenic rocks of both fresh and weathered stages (Konsa 1986a, b). The typologies of zircon do not change remarkably in the weathering profile. Thus it should be possible to study local sources of clastic sedimentary rocks regardless the weathering stage of the crystalline rocks subcropping under the sedimentary cover. We will pay most attention to those varieties of zircon that are related only to distinct types of rocks compared to the surrounding bedrock and can be easily recognised after deposition into the overlying sediments (Figs. 4a and b).

The most remarkable zircon grains occurring in biotite-amphibole-pyroxene and two-pyroxene gneisses (drill core 173) are rounded in shape. Based on the degree of roundness and overgrowth, three types of zircon grains can be distinguished. (1) Subhedral zircon (up to $26 \%$ of zircon grains in a sample) is cracked, often non-transparent, contains abundant inclusions and has subrounded 
4 a

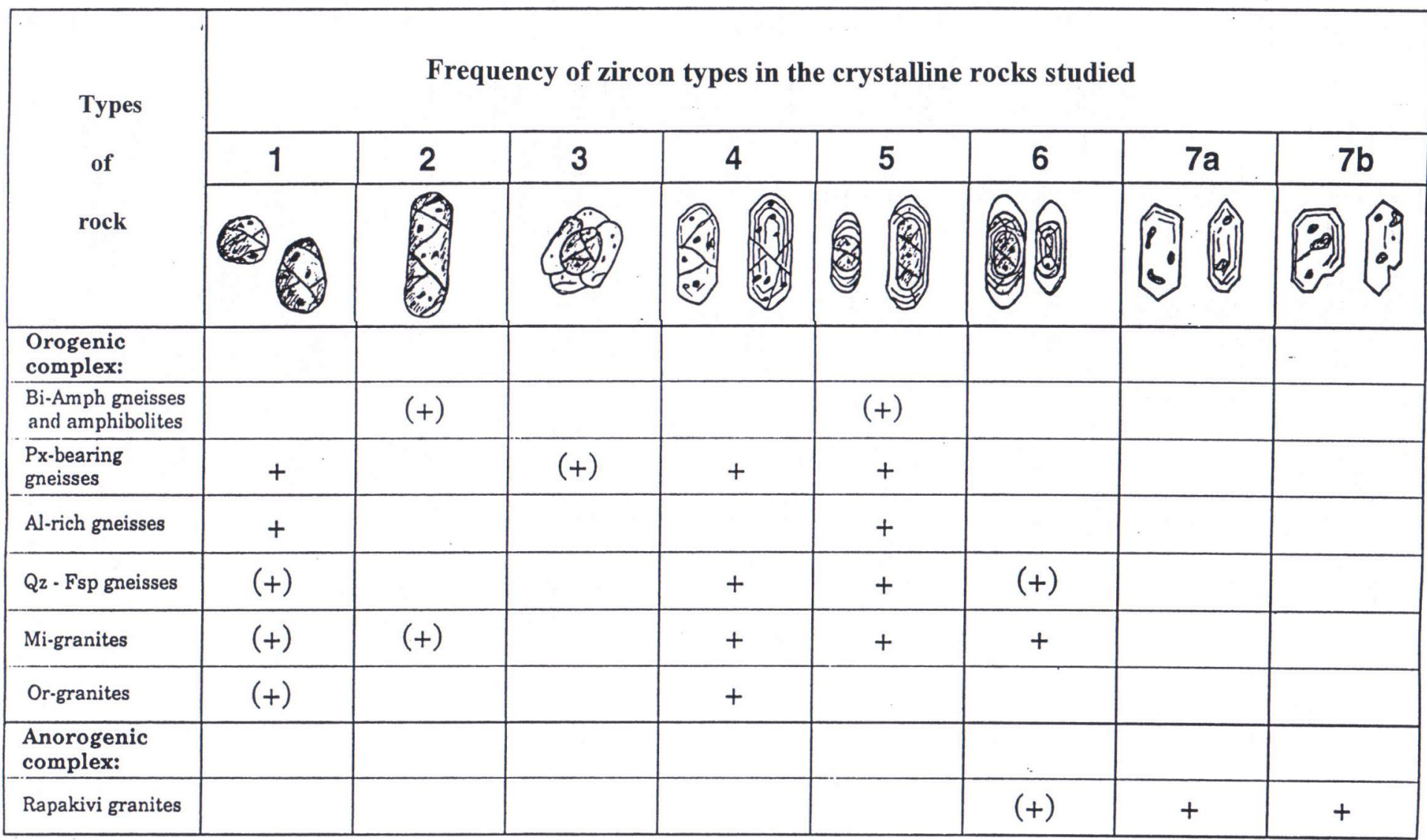

Frequency: + - abundant, $(+)$ - rare

Minerals: Amph - amphibole, $\mathrm{Bi}$ - biotite, Fsp - feldspar, Mi - microcline, Or - Orthoclase, $\mathrm{Px}$ -

pyroxene

Fig. 4. Frequency of zircons of different typology in the crystalline rocks studied. a. distribution of major types. 

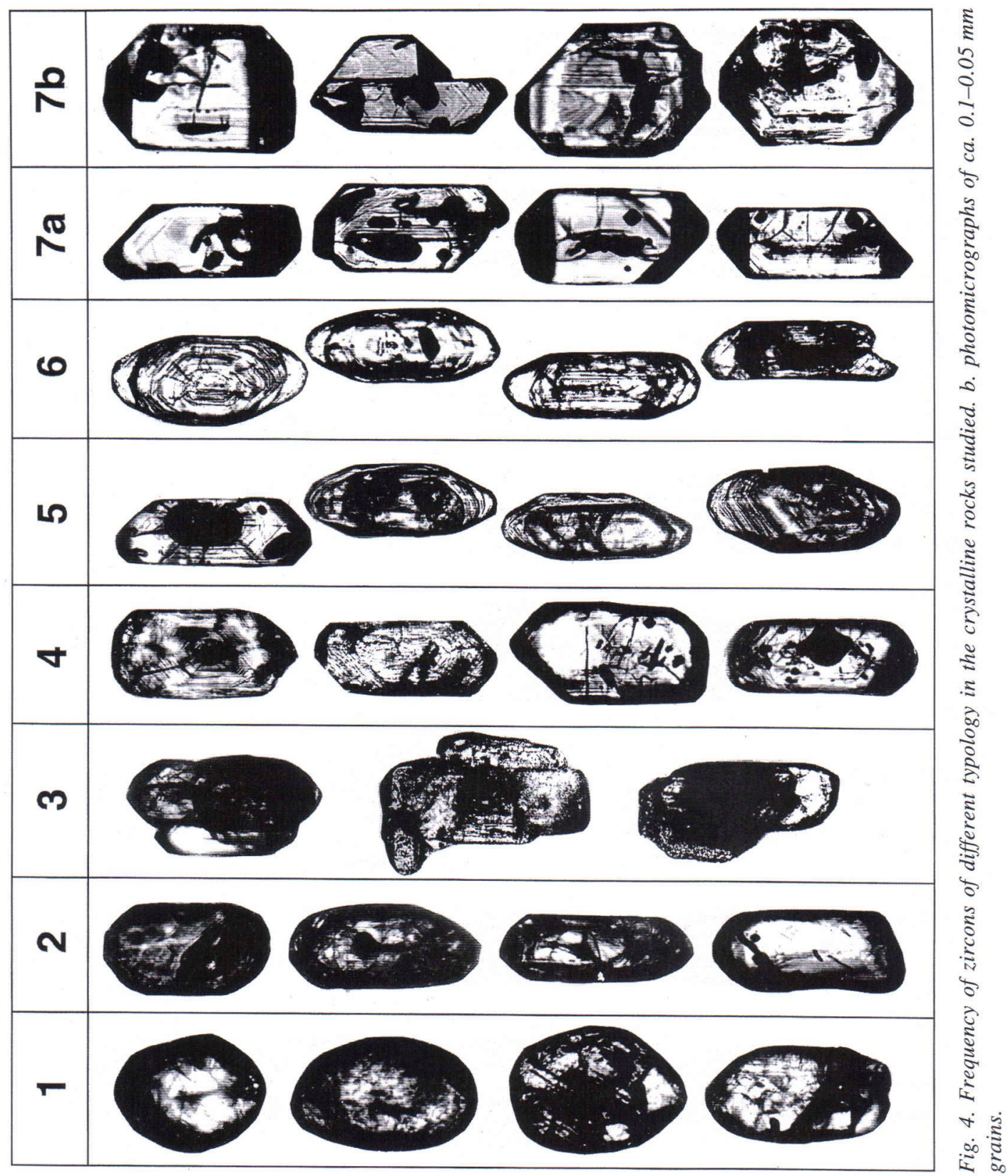

f

(often almost subhedral) dark zircon as a core. (2) Subrounded zircon (up to $50 \%$ ) is dark, metamict, cracked and rich in inclusions. (3) Irregular or peculiar aggregate-like zircon.

In granite gneisses (cores 423 and 555) three zircon types (generations) can be distinguished. (1) Zircon of the earliest generation occurs as a core and as independent subrounded or rounded, translucent, cracked and inclusion-rich crystals (Fig. 4b). (2) Zircon of metamorphic type is the most 
abundant. It is represented by subhedral translucent grains that have zoning, cracks and inclusions, and are often metamict. This zircon also occurs frequently as coatings or rims on grains of the former type. (3) Zircon that is euhedral or subhedral, colourless and transparent. Its formation is considered to be related to metasomatic processes. Usually it forms rims and growths on zircon grains developed earlier. In general, zircon of granite gneisses is often corroded and metamict. Characteristic are also the so-called "pin-shaped" crystals (growing longitudinally in one direction) and crystal intergrowths.

In biotite-amphibole gneisses (core F159) zircons are mostly subhedral, transparent or translucent crystals (Fig. 4b). Quite often there is zoning, and inclusions are frequent. Presumably, the formation of this type took place in the course of regional metamorphism. Pre-metamorphic rounded cores have not been found.

In amphibolites (core F147) two main zircon types can be distinguished (Fig. 4b): relict and metamorphic. The latter is more widespread (up to $60 \%$ ), found in rocks of the amphibolite facies. Relict zircons (up to $30 \%$ ) are subrounded, lightcoloured, transparent or translucent and do not show zoning. Relict zircon may occur either as independent crystals or cores (in most part) in metamorphic zircon. It may in turn contain older zircon as a core. Metamorphic zircon occurs either as colourless or yellowish-brown, translucent or transparent, independent crystals or rims on older zircon. Metamorphic zircon is subhedral in shape. The crystals are metamict, contain inclusions, are characterised by zonation and are sometimes corroded.

In biotite plagiogneisses (core F129) zircon is represented by subhedral and subrounded, translucent, occasionally metamict, often cracked crystals (Fig. 4b). Zoning and inclusions are quite abundant. Rounded zircon grains and zircon containing cores are absent.

Al-rich gneisses and biotite gneisses have been studied from numerous core sections of the Alutaguse zone (cores F144, F146, F147, F150, F154, F156). The rocks considered were subjected to amphibolite facies metamorphism. Two zircon generations can be distinguished (Fig. 4b). (1) Small subrounded or rounded grains are translucent or opaque, often cracked, rich in inclusions and zoned. This relict zircon occurs as independent crystals and as cores in younger zircon. (2) Subhedral well-developed crystals with short prisms are transparent or translucent, often metamict and corroded. These types are rarely found occurring independently. Usually this zircon occurs as shells or growths on zircon of an earlier generation. Some grains bear marks of corrosion. About $90-100 \%$ of the zircon grains studied in the Al-rich gneisses show signs of rounding or have rounded cores. The occurrence of abundant rounded relict zircon grains in the rock types under consideration may be a most convincing indicator of the formation of these metamorphic rocks on account of sedimentary rocks.

In high-grade charnockites-enderbites (core 555) zircon is subhedral and prismatic, or approximately so, in shape. Less frequently, subrounded or rounded zircon grains are recorded. Typologically three zircon types (generations) can be distinguished (Fig. 4b). (1) Translucent or opaque, cracked, often inclusion-rich, subrounded or rounded zircon that is found as cores or as independent crystals. (2) Subhedral, translucent or opaque, inclusion-rich, cracked zircon that occurs either as independent crystals lacking cores or forms shells or growths on zircons of an earlier generation. (3) Zircon, which usually occurs as rims and growths on the zircon of the first and second generations. In small quantities it is also found as independent, larger, subhedral or euhedral, light brownish translucent crystals.

The typology of zircon in granite migmatites formed in the rocks of the amphibolite transitional to granulite facies was studied in the Jõhvi (core F169) and Tapa zones (core F164). Granite migmatites occur as thin veins in almost all drill cores and less frequently they are found as separate large bodies (plagiomicrocline or microcline granites and plagiogranites). The whole assemblage of metamorphic rocks and migmatite granites is polymetamorphic in nature (Puura et al. 1983). Zircon crystals in these rocks are of a rather variable shape. Therefore, in this paper, some of the 
migmatite varieties are treated separately. In the Jõhvi zone (core F169), zircon of an older generation is represented by subrounded and rounded, translucent, inclusion-rich, often cracked crystals occurring either as separate grains or as cores in younger, subhedral zircon (Fig. 4b). Subhedral zircon of an earlier generation (up to $85 \%$ of the zircon) forms either coatings on older zircons or occurs as separate crystals. The zircon is translucent or opaque, rich in inclusions and cracked. Zoning is weakly developed. Subhedral zircon grains may also have growths originating from the third, youngest generation. In plagiogranites (core F163), up to $25 \%$ of zircon grains have a subrounded shape. The zircon is translucent and inclusion-rich. Frequently, such zircon occurs as cores in younger, subhedral crystals. Subhedral zircon (up to $75 \%$ ) is translucent or transparent, often consisting of cracked crystals, without zoning and inclusions. Less common are subhedral, translucent, brownish crystals with distinct zoning. Plagiomicrocline granites (cores F161, F168) contain two types of zircon. Up to $25 \%$ of the grains are subrounded (Fig. 4b), translucent, brownish, cracked and with cores. Most frequent is a light brownish, more rarely yellow or colourless prismatic zircon (up to $75 \%$ ). This zircon is often opaque, cracked and rich in inclusions. Cores are absent. Zoning is absent or weakly developed. The rounded zircon of relicts of charnockites-enderbites, migmatite granites, migmatites and plagiogranites suggests a sedimentary origin of the protoliths of these rocks. In all the described rock types, the metamorphic subhedral zircon prevails (Fig. 4). These crystals may bear metasomatic growths or coatings (particularly in the charnockites-enderbites).

The Riga rapakivi batholith and several minor plutons and bodies of porphyritic potassium granites represent the anorogenic rapakivi granites of the region. Characteristics of the zircons from the porphyritic potassium granites are described based on the samples from the Neeme pluton (core F508). Euhedral or prismatic subhedral crystals (Fig. 4b) represent magmatogenic zircon. The crystals are colourless or light-coloured, transparent, rarely translucent, with abundant inclusions.
Zoning and fractures are widespread. The crystal surface is smooth, occasionally slight hatching is observed. Often crystals grow in only one direction, forming so-called pin-shaped crystals. Some grains are metamict along zoning and cracks, and are rarely corroded.

The zircon of the rapakivi granites proper was studied in the samples from the Riga batholith (core 500). There occur well-developed euhedral and subhedral prismatic crystal forms (extension 1.5-4.0, rarely more) (Fig. 4b). Zircon occurs commonly as colourless or light-coloured transparent crystals, less frequently they are greenish, flattened and with relatively low birefringence. Zoning is absent. Thickened crystals occur in abundance. Some grains are cracked and corroded. All types of anorogenic rapakivi granites contain only euhedral or subhedral zircon.

\section{COMPOSITION AND ZIRCON TYPOLOGIES OF THE LOWERMOST SEDIMENTARY COVER}

The oldest sedimentary rocks immediately overlying the basement are Upper Vendian or Lower Cambrian strata (Fig. 2). In NE and central Estonia these rocks belong to the Oru and Moldova members of the Vendian Gdov Formation (Mens \& Pirrus 1980). In southwestern Estonia and western Latvia, the basement is overlain by the Lower Cambrian Balti, Liivi and, locally, Aisčiai series.

The Gdov Formation rests on the basement. Its thickness decreases from the northeast $(58.3 \mathrm{~m}$ in core 311 Mustajõe) to central Estonia $(0.2 \mathrm{~m}$ in core 91 Viljandi). The formation consists predominantly of multicoloured sandstones and siltstones (Mens \& Pirrus 1997) that consist of quartz and up to $50 \%$ of feldspars. Muscovite and biotite are subordinate. Illite and kaolinite permanently represent clay minerals (Pirrus 1992).

The Oru Member, the lower unit of the Gdov Formation, occurs locally (Fig. 2a). It consists of very poorly sorted gravely to clayey deposits. Considering the mineral composition, these deposits resemble the weathering mantle of the underlying crystalline basement (weathering stage III, 
rarely stage II). Therefore the sedimentary rocks of the Oru Member may be considered as originating from the local weathering profile of the basement after being transported a small distance. To achieve data on inheritance of the sedimentary cover minerals from the local sources, the study of sedimentary rocks of the Oru Member overlying different rock types of the basement could be most promising (Table 1). However, the bulk mineral composition of the Oru Member does not show any dependence on the local primary rock composition of the basement. In the fraction of 0.1-0.05 mm, quartz, altered microcline and plagioclase, muscovite, altered biotite, and clay minerals are the rock-forming constituents. Ilmenite and Fe-hydroxides are subordinate, and the accessory minerals are zircon, tourmaline and sphene (Fig. 3).

In the Oru Member, zircon often inherits the features from the underlying basement rocks (Konsa 1987). Zircon of the Oru Member lying on granulitic granite gneisses and charnockites-enderbites was studied in southeastern Estonia (cores 423 Põlva and 555 Elva, Fig. 1). Three zircon types were distinguished (Fig. 5, below): (1) subrounded or rounded crystals, often metamict, cracked and rich in inclusions; (2) subhedral, translucent, cracked and inclusion-rich grains (the predominant type in the sample); (3) subhedral, clean, transparent zircon, frequently occurring as rims and growths and less frequently as independent crystals. Apart from the described zircon grains, the samples also contain irregular grains (fragments of crystals), which have possibly formed from cracked and other grains during deposition. The zircon types of the Oru Member are closely similar to those of the directly underlying granite gneisses. We conclude that this zircon originates from the weathering mantle of the underlying granite gneisses and charnockites-enderbites.

The zircon of the Oru Member overlying weathered biotite-amphibole gneisses and biotite-plagiogneisses (Fig. 5) was studied in core F159. Up to $60 \%$ of the zircon occurs here in the form of irregular grains. The proportion of subhedral zircon in the sample is up to $30 \%$ and that of subrounded zircon up to $15 \%$. The zircon is colour- less, transparent or translucent, rich in inclusions, cracked, corroded and often metamict. Cores and growths have not been found. The sedimentary rocks of the Oru Member under consideration lie on strongly weathered biotite-amphibole gneisses. Zircon of the Oru Member, however, is similar to that of the biotite-plagiogneisses alternating with biotite-amphibole gneisses.

The zircon of the Oru Member overlying aluminium-rich gneisses and biotite gneisses (Fig. 5) was studied in eight samples from the cores shown in Table 1. Samples from these cores (except for F153) contain subrounded and rounded zircon grains and fragments of crystals. Subhedral grains occur in relatively small numbers. In core F153, most of the zircon of the Oru Member (70-75\%) is subhedral, translucent, inclusion-rich, zoned and often metamict. Subrounded and irregular grains are less common. Consequently, the zircon described is different from that of the immediately underlying biotite-amphibole gneisses or biotiteplagioclase gneisses, but resembles the zircons of the migmatite granites occurring somewhere in the neighborhood, probably east of drill hole F153. Presumably the granites could serve as a source for the sedimentary rocks of the Oru Member in the F153 core section.

To sum up, we deduce that zircon of the Oru Member is characterised by a relatively great diversity, lateral variation and notable similarity with the zircons from the underlying or close-lying rocks of the crystalline basement. The samples with recognisable similarity to those of the underlying basement rocks have been found in an interval of $0.5-1.5 \mathrm{~m}$ above the weathered crystalline basement - sedimentary cover discontinuity.

The next unit, the Moldova Member of the Gdov Formation, is of continuous distribution in northeastern Estonia (Fig. 2). Outside the local occurrences of the Oru Member, this unit is in contact with the basement (Table 1). Poorly sorted immature polymict clastic deposits represent the Moldova Member. The member mostly consists of yellowish or pinkish feldspathic sandstones, with a few interlayers of multicoloured (often reddish) siltstones. Apart from quartz and feldspars, biotite often occurs as a major miner- 


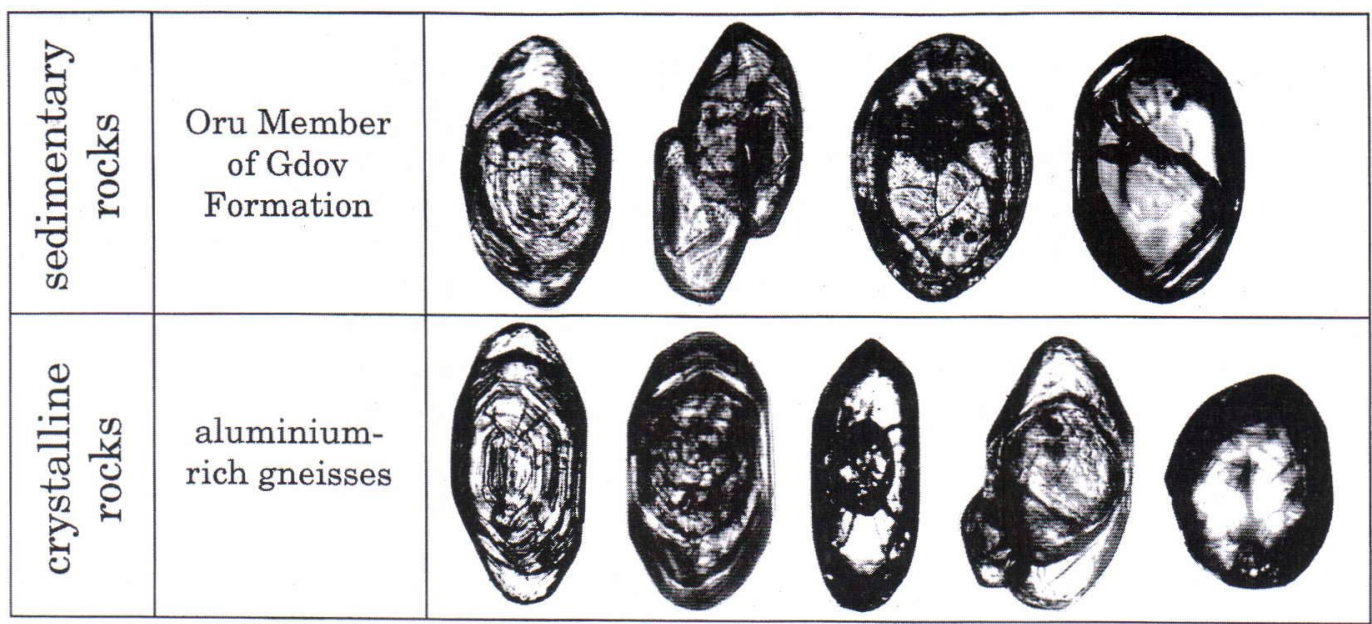

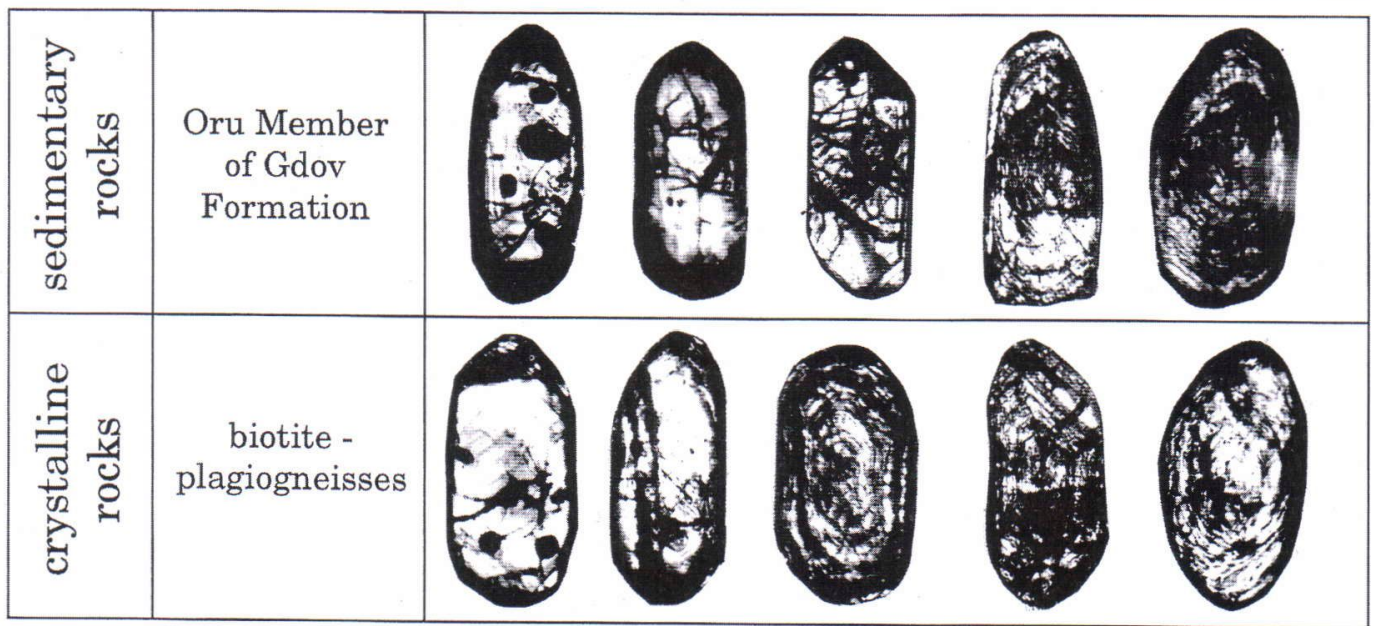

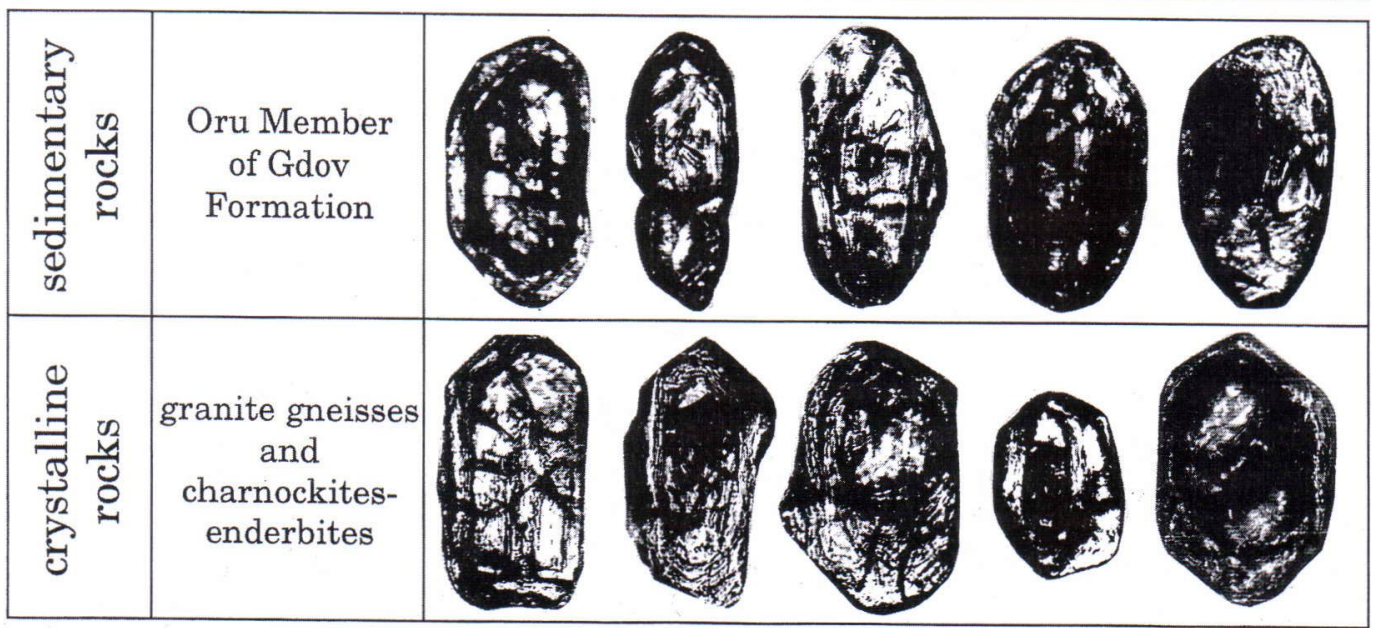

Fig. 5. Morphologies of 0.1-0.05 mm zircons of Precambrian crystalline rocks and directly overlying Vendian sedimentary rocks (northeastern Estonia). 
al. The amount of heavy minerals is usually low. The bulk mineral composition of this member suggests that the original source material was derived from a mixture of the mature (stage III) and middle (stage II) part of the weathering profile developed on the basement rocks of various compositions.

Zircon of the Moldova Member (Fig. 6) was studied from basal conglomerates and sandstones (altogether 33 samples from 16 sections, Table 1). The samples characterise beds up to $43 \mathrm{~m}$ from the basement contact. In 12 studied sections the sedimentary rocks of the Moldova Member lie directly on the crystalline basement, in four sections (Table 1), however, on the Oru Member. The most widespread zircon type in the Moldova Member are subhedral, short-prism, colourless or yellowish crystals, which are often corroded, cracked, with weak zoning, inclusion-rich and sometimes metamict (Fig. 6). Subhedral crystals often contain subrounded or rounded dark cores (zircon of an earlier generation). These subrounded grains also occur as separate grains. This type of zircon is less cracked, rich in inclusions and zoned. The sedimentary rocks may also contain a small amount of euhedral, transparent, colourless and intergrown crystals, as well as strongly elongated needle-shaped grains. The features indicating the direct inheritance of the mineral composition of the Moldova Member from the underlying weathered rocks of the basement were not distinguished. Here, the zircon varieties are of a more regular horizontal and vertical distribution, and of almost stable average content both in areas of direct contact to the weathered basement and in places where the Moldova Member is isolated from the basement by the Oru Member. This implies repeated redeposition, long-term transportation and great distances to the source of the original material.

In southwestern Estonia the weathered basement is overlain by the Taebla Member of the Voosi Formation. Light-coloured siltstones and fine-grained sandstones mostly represent the Taebla Member (Table 2, Fig. 2b) with solitary greenish-grey clay interlayers (core 173). The light fraction comprises quartz, feldspars and micas. Authi- genic minerals (pyrite, Fe-oxides and Fe-hydroxides, glauconite and leucoxene), micas and dark ore minerals dominate the heavy fraction. Allogenic transparent minerals show the predominance of zircon, followed by tourmaline, garnet, apatite, Timinerals, amphiboles and pyroxenes. This mineral composition of the member shows no similarity to the underlying strongly weathered pyroxenebearing rocks of the basement.

Zircon typomorphic varieties of the Taebla Member were studied in core 173 (Seliste; Fig. 7) up to $20 \mathrm{~cm}$ from the basement. Two zircon types were recorded; (1) euhedral (up to $7 \%$ of the zircon) or subhedral (up to $38 \%$ ) grains that are inclusion-rich, usually cracked and sometimes zoned, and (2) subrounded zircon (up to $12 \%$ ). Apart from these types, irregular small grains amount up to $40 \%$. Subrounded zircons are also found as cores in subhedral zircon crystals. The zircon from this member closely resembles zircons of the underlying two-pyroxene gneisses (an association of subhedral, cracked, inclusion-rich grains, often with cores and of subrounded or irregular shape). The occurrence of euhedral crystals and the abundance of subhedral grains, however, indicate that some of the material originates from other sources.

The Soela Formation, immediately overlying rapakivi granites in SW Estonia, was studied in core 500 (Ruhnu; Table 2, Fig. 2b). The Soela Formation is represented by light, coarse-grained siltstone, containing greenish-grey clay interlayers and lenses. In the $0.1-0.05 \mathrm{~mm}$ fraction, among light minerals, quartz dominates, supplemented by feldspars and micas. Among allogenic transparent minerals, tourmaline and zircon prevail, followed by Ti-minerals, garnet, apatite and hornblende. Ilmenite is common.

Zircon was studied in one sample (Table 1). Irregular colourless grains with small inclusions dominate (up to $70 \%$ ) (Fig. 7), while subhedral and subrounded grains are less common. Based on the zircon, it may be suggested that the initial source material of the basal sedimentary rocks studied does not originate from the underlying rocks only, but was possibly derived from several sources via redeposition and mixing. 


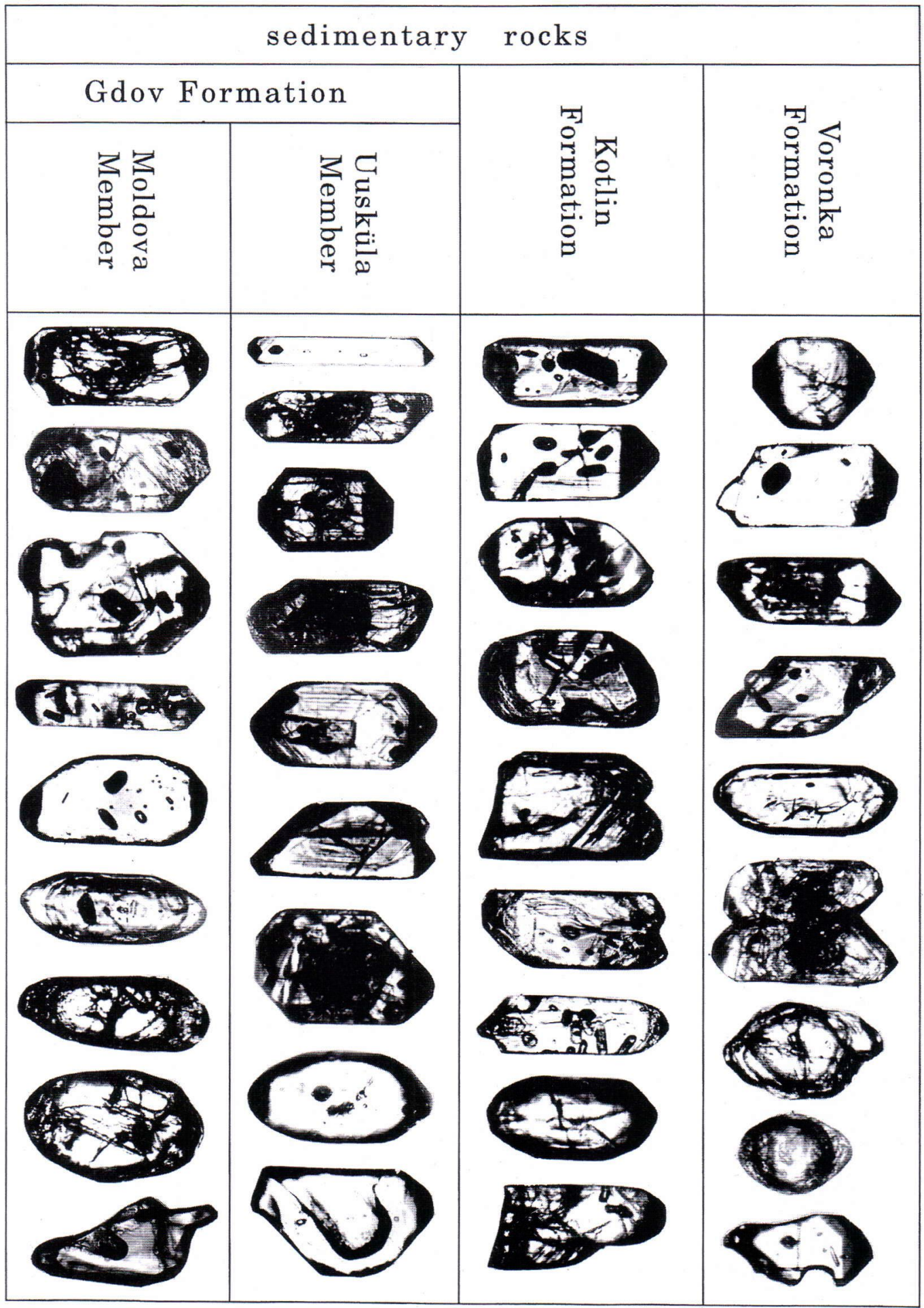

Fig. 6. Typologies of 0.1-0.05 mm zircons in Vendian sedimentary rocks. 


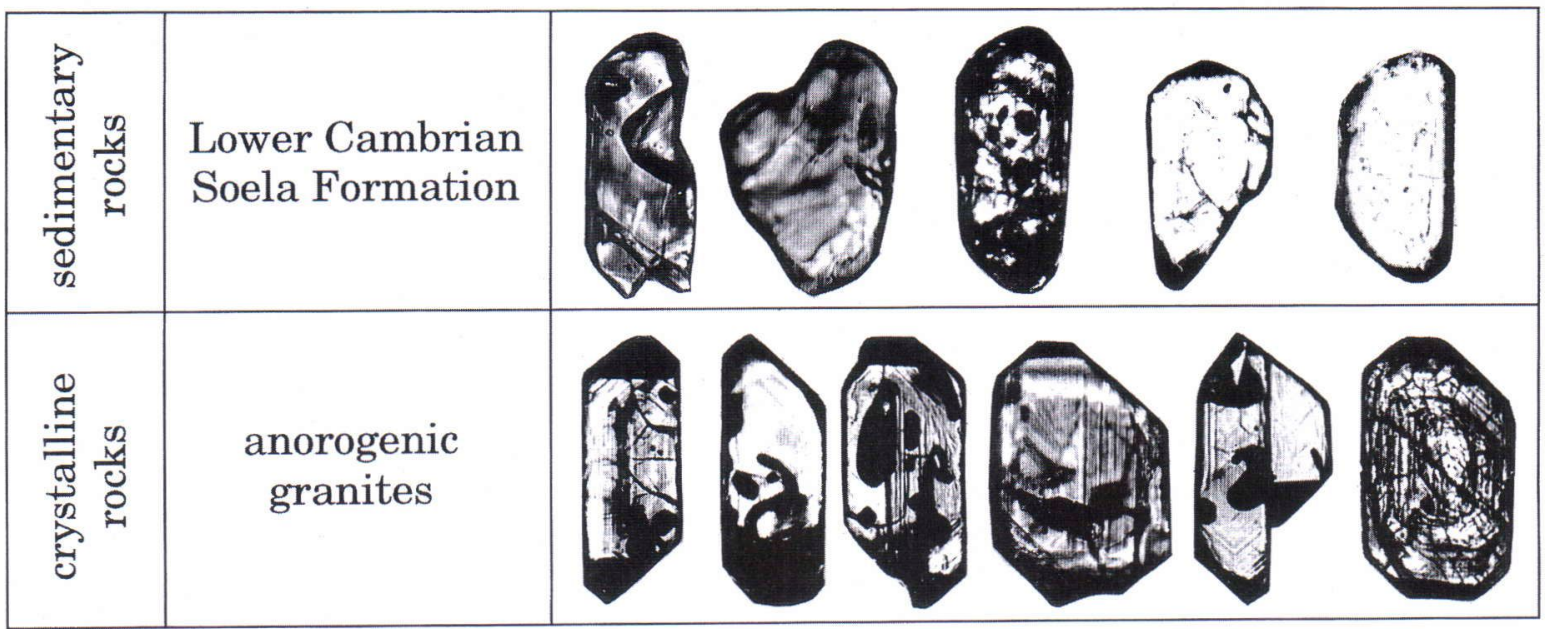

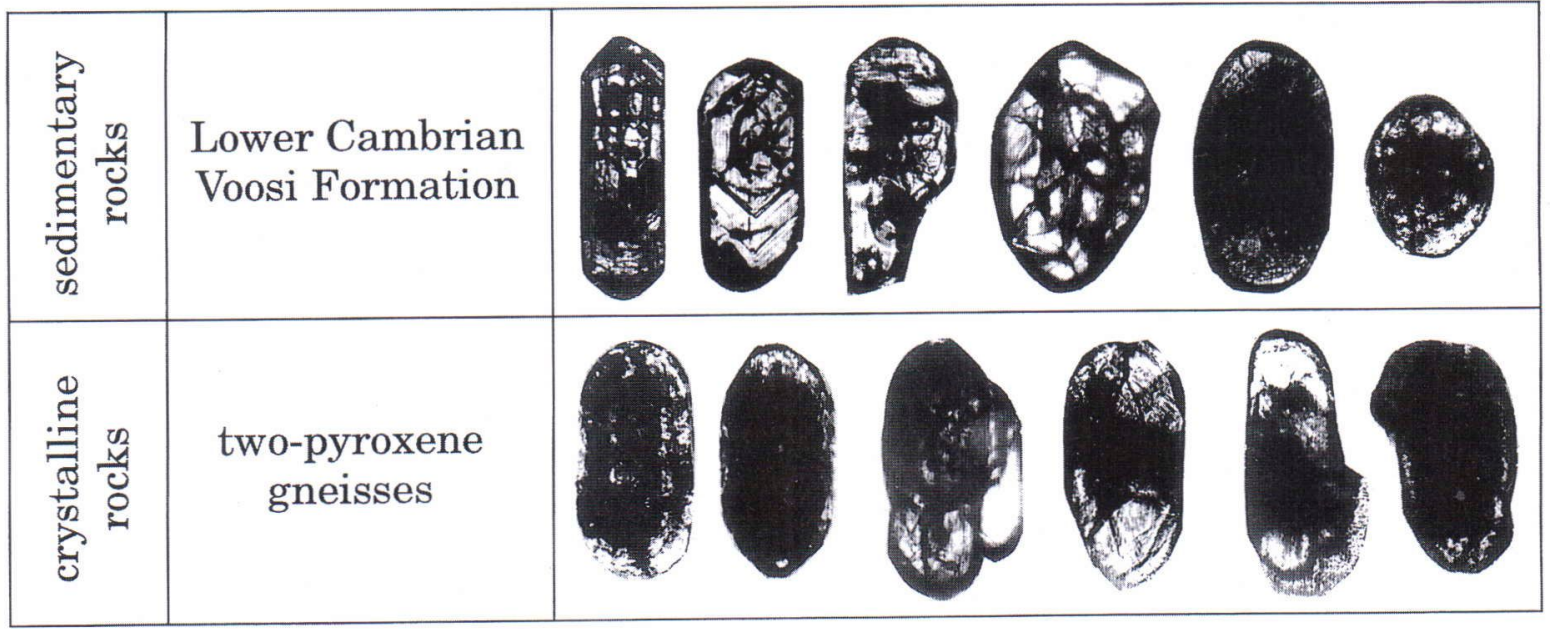

Fig. 7. Morphologies of 0.1-0.05 mm zircons of Precambrian crystalline rocks and overlying Lower Cambrian sedimentary rocks (southwestern Estonia).

\section{COMPOSITION AND ZIRCON}

\section{TYPOLOGIES OF THE OVERLYING} VENDIAN DEPOSITS

In the sedimentary rocks isolated from the basement by the layers discussed above, namely in the Uuskuila Member of the Gdov Formation and the Kotlin and Voronka Formations, the bulk mineral composition and association of zircon typological varieties imply the derivation of the clastic material from various sources.

The Uusküla Member (Fig. 2a) is characterised by alternation of multicoloured siltstone and clay- stone layers with few interlayers of sandstone. The light-coloured rock-forming minerals are quartz, feldspar and micas. The heavy fraction comprises ilmenite, leucoxene and other Ti-minerals, pyrite, carbonates, zircon, tourmaline and amphiboles. Zircon of the Uusküla Member was studied in 53 samples from 18 core sections (Table 1) in the interval up to $12-57 \mathrm{~m}$ above the weathered basement rocks. The most widespread (up to 60\%) zircon is subhedral, colourless and cracked, less commonly uncracked (Fig. 6). Zoned subhedral crystals are also present. Subhedral zircon often contains a core of subrounded zircon. Independent 
subrounded zircon makes up 5-15\%. Transparent euhedral zircon, also including needle-shaped varieties (elongation 10 ), amounts up to $10 \%$. $\mathrm{Nu}-$ merous grains are corroded and thickened crystals also occur. The characteristics of the zircon from the Uusküla Member, as well as the mineral composition of these sedimentary rocks, show that the formation of the member was greatly affected by weakly weathered crystalline rocks of different compositions, possibly far from our study area.

The overlying Kotlin Formation is represented by grey thin-bedded claystones containing siltstone interlayers. Zircon from siltstone was studied in 13 samples from 9 core sections (Table 1) in the interval of 36-96 m from the basement. It resembles the zircon of the Gdov Formation; rounded grains are almost absent, subrounded grains amount to less than $10 \%$, subhedral crystals up to $50 \%$ and euhedral crystals up to $10 \%$ of zircon in a sample. Irregular grains are quite frequent. Zircon is transparent, colourless, often cracked, inclusion-rich and rather often zoned. Zircons containing cores were not found (Fig. 6).

In the sandstones and siltstones of the Voronka Formation zircon was studied in 28 samples of 12 sections (Fig. 1, Table 1) 34-102 m above the basement. Subhedral crystals dominate the zircons of the Voronka Formation (Fig. 6). Subhedral zircon usually consists of short prisms and is colourless, transparent or metamict and often rich in inclusions. Crystals are less cracked than those in the Kotlin Formation. Subrounded grains are not numerous, but compared to the zircon of the Kotlin Formation, the proportion of subrounded grains is higher. Some subrounded grains have rounded cores but separate rounded grains are almost absent. Compared to the Kotlin Formation, the proportion of euhedral crystals is somewhat smaller. Irregular, often corroded grains are quite abundant.

\section{CONCLUSIONS}

Usually, the source problem in clastic sedimentation has been studied in terms of the lateral sequence erosion - transportation - deposition of detrital material. If the erosional process is highly effective, the lateral distance between the source and deposition areas is often great. This is not the case when the source, transportation and deposition areas of the early stage of sedimentation in the internal parts of the East-European Craton, and on Precambrian cratons on the whole, are discussed.

Before the beginning of the craton-scale sedimentation, the Precambrian orogenic and anorogenic bedrock was everywhere deeply eroded so that mainly high-grade metamorphic and plutonic rocks are now exposed on the surface of the basement. The Meso- to Neoproterozoic geomorphologic cycle was completed to a high degree. When the sedimentation started, the surface of the basement represented an almost ideal plain with few remnant highs and without any major erosional depressions. The late Neoproterozoic to early Phanerozoic transgression proceeded very slowly. The transgression which started in the central part of the East-European Craton in the middle Vendian reached the westernmost part of the craton in late Early Cambrian, that is some $50 \mathrm{Ma}$ later. The transgression process was not hydrodynamically active. Thus, the products of weathering survived well almost everywhere.

The most important result of our mineralogical study is that shortly after the early stages of sedimentation the proportion of local sources of sediments dramatically decreased, and distant sources of detrital material became more important. Already in the Uusküla deposits prevail zircons of a probable distant source. Therefore, remarkable mineralogical inheritance could be found only in the immature sedimentary rocks immediately overlying the weathered basement. The upward decrease in the connections between the crystalline basement and the sedimentary cover can be explained only if changes of the source areas and mixing during the sedimentary process are considered.

Quartz and zircon were resistant to weathering, while most dark rock-forming minerals, such as biotite, amphibole, pyroxene and garnet, as well as feldspars were decomposed already in the lower part of the weathering profile. The majority of 
accessory (like apatite and tourmaline) and ore (e.g. magnetite, ilmenite and sulphides) minerals present in the fresh crystalline rocks did not survive in the weathering profile. Quartz typologies in the basal sedimentary strata gave just minor indications on possible source rocks. Thus, zircon is practically the only mineral that has carried information on the links between the crystalline basement and the sedimentary cover.

The bulk mineral composition of the weathering profile on the basement and of the Vendian and Cambrian deposits suggest cool to moderate climate conditions of formation (Pirrus 1992). This agrees with the palaeomagnetic data on the southern near-pole position of the Baltica palaeocontinent at that time. The Late Vendian basin, which first covered the NE half of the Estonian territory, had a large bay-type configuration and low water salinity compared to ocean water (Pirrus 1992). The basal layers of the Oru, Moldova and other lowermost sedimentary units were deposited during the gradual transgression of the Late Vendian basin. In cases where large enough areas of certain specific zircons occur, local source areas of the basal units, e.g. the Oru Member, can be distinguished. For example, sources of certain zircons can be connected with granites of the rapakivi family. However, the distinct local influence of the basement zircon typologies upper in the sedimentary cover is limited. As a local phenomenon it appears in the profiles in the Oru Member up to about $2 \mathrm{~m}$. In the Moldova Member, zircons of possibly mixed, local and distant basement origin can be found. In the units upwards, zircons of different, probably mainly of distant crystalline origin, can be found. Starting from the middle of the Moldova Member, identification of the local inheritance of distinct portions of zircon or other minerals is, however, impossible. In the Voosi Formation, zircons of local basement origin do not occur, even at the contact of the basement. Taking also into consideration volumetrical calculations, it is clear that distant sources of detrital material and clay became significant.

To conclude with, the weathered basement sedimentary cover mineralogical relationships are important in the study of the early intracratonic sedimentation. Large parts of the over $200 \mathrm{~m}$ thick Upper Vendian and Lower to Upper Cambrian sequence of the Baltic region and all over the EastEuropean Craton were not derived from the intracratonic areas of erosion. This conclusion is supported by palaeogeographic mapping of the EastEuropean Craton (Nikishin et al. 1996). It raises a larger problem of the supply of the detrital material into the interior of the East-European Craton. The ages of possible source areas could be found using isotope age determinations of zircons from the Vendian and Cambrian sedimentary suites.

ACKNOWLEDGEMENTS. Dr. Herbert Viiding (1929-1988) initiated this project. Field and laboratory studies were completed at the Geological Survey of Estonia and the Institute of Geology, Tallinn. The final stage of investigation was supported by the Estonian Science Foundation (grants 2063 and 2191). We appreciate the comments by Prof. D. Kaljo, Dr. K. Mens, Dr. Ivar Puura and an anonymous referee that enabled to improve the manuscript.

\section{REFERENCES}

Bogatikov, O.A. \& Birkis, A.P. 1973. Magmatizm dokembrija Zapadnoj Latvii. Moscow: Nauka. 137 p. (in Russian, translated title: Precambrian magmatism in West Latvia)

Bogdanova, S.V., Pashkevich, I.K., Gorbatschev, R. \& Orlyuk, M.I. 1996. Riphean rifting and major Palaeoproterozoic crustal boundaries in the basement of the East European Craton: geology and geophysics. Tectonophysics 268, 1-21.

Bycksteeg, A., Bauer, W. \& Spaeth, G. 1995. Typologic studies of zircon populations from gneisses of the northern Heimefrontjella (Antarctica). Neues Jahrbuch für Geologie und Paläontologie 197, 253-273.

Gorbatschev, R. \& Bogdanova, S.V. 1993. Frontiers in the Baltic Shield. Precambrian Research 64, 3-21.

Klein, V. \& Konsa, M. 1986. Distribution of accessory minerals in the North-Estonian Lower Proterozoic metamorphic complexes. Proceedings of the Academy of Sciences of Estonian SSR, Geology 35, 47-52. (in Russian, with English summary)

Klein, V., Konsa, M. \& Niin, M. 1994. On mineralogy of the porphyritic potassium granites of small massifs in the northern Estonian basement. Proceedings of the Estonian Academy of Sciences, Geology 43, 165-176. 
Koistinen, T. (ed.) 1994. Precambrian basement of the Gulf of Finland and surrounding area $1: 1$ mill. Espoo: Geological Survey of Finland.

Koistinen, T. (ed.) 1996. Explanation to the map of Precambrian basement of the Gulf of Finland and surrounding area 1:1 mill. Geological Survey of Finland, Special Paper 21, 21-57.

Konsa, M. 1986a. Typomorphic variations of zircon in the crystalline basement of Estonia. Proceedings of the Academy of Sciences of Estonian SSR, Geology 35, 19. (in Russian, with English summary)

Konsa, M. 1986b. Zircon in pre-Vendian weathering rind of Estonian crystalline rocks. Proceedings of the Academy of Sciences of Estonian SSR, Geology 35, 160-162. (in Russian, with English summary)

Konsa, M. 1987. Typomorphic features of zircon in basal layers of sedimentary rocks of the North Baltic. Proceedings of the Academy of Sciences of Estonian SSR, Geology 36, 97-103. (in Russian, with English summary)

Kuuspalu, T. 1975. Granity rapakivi kristallicheskogo fundamenta Estonii. Acta Universitatis Tartuensis 359, 76141. (in Russian; translated title: Rapakivi granites of the crystalline basement in Estonia)

Kuuspalu, T., Vanamb, V. \& Utsal, K. 1971. O mineralogii kory vyvetrivanija kristallicheskogo fundamenta Estonii. Acta Universitatis Tartuensis 286, 52-163. (in Russian; translated title: Mineralogy of the weathering mantle on the crystalline basement of Estonia)

Mens, K. \& Pirrus, E. 1980. K stratigraficheskoj nomenklature vendskikh otlozhenij Estonii. Proceedings of the Academy of Sciences of Estonian SSR, Geology 29, 4954. (in Russian; translated title: Stratigraphy of the Vendian deposits of Estonia)

Mens, K. \& Pirrus, E. 1986. Severo-Pribaltijskij facial'nyj profil' venda i kembrija. In: Mens, K. \& Pirrus, E. (eds.) Fatsii i stratigrafiya venda i kembriya zapada Vostochno-Evropejskoj platformy. Tallinn: Estonian Academy of Sciences Publishers, 7-23. (in Russian; translated title: North Baltic facial profile of the Vendian and Cambrian deposits)

Mens, K. \& Pirrus, E. 1997. Vendian. Cambrian. In: Raukas, A. \& Teedumäe, A. (eds.) Geology and Mineral Resources of Estonia. Tallinn: Estonian Academy of Sciences Publishers, 35-48.

Nikishin, A.M., Ziegler, P.A., Stephenson, R.A., Cloetingh, S.A.P.L., Furne, A.V., Fokin, P.A., Ershov, A.V., Bolo- tov, S.N., Korotaev, M.V., Alekseev, A.S., Gorbachev, V.I., Shipilov, E.V., Lankreijer, A., Bembinova, E.Yu. \& Shalimov, I.V. 1996. Late Precambrian to Triassic history of the East European Craton: dynamics of sedimentary basin evolution. Tectonophysics 268, 22-63.

Pirrus, E. 1992. Freshening of the Late Vendian basin on the East-European Craton. Proceedings of the Estonian Academy of Sciences, Geology 41, 115-123.

Pupin, J.P. 1980. Zircon and granite petrology. Contributions to Mineralogy and Petrology 73, 207-220.

Puura, V. \& Flodén, T. 1999. Rapakivi-granite-anorthosite magmatism - a way of thinning and stabilisation of the Svecofennian crust, Baltic Sea Basin. Tectonophysics 305, 75-92.

Puura, V. \& Huhma, H. 1993. Palaeoproterozoic age of the East Baltic granulite crust. Precambrian Research 64, 289-294.

Puura, V., Vaher, R., Klein, V., Koppelmaa, H., Niin, M., Vanamb, V. \& Kirs, J. 1983. The Crystalline Basement of the Estonian Territory. Moscow: Nauka. 208 p. (in Russian, with English summary)

Rämö, O.T., Huhma, H. \& Kirs, J. 1996. Radiogenic isotopes of the Estonian and Latvian rapakivi granite suites: new data from the concealed Precambrian of the EastEuropean Craton. Precambrian Research 79, 209-226.

Rozanov, A.Yu. \& Lydka, K. (eds.) 1987. Paleogeography and lithology of the Vendian and Cambrian of the western East-European Platform. Warsaw: Wydawnictwa Geologiczne. 114 p.

Sutton, S.J. \& Maynard, J.B. 1996. Basement unconformity control on alteration, St. Francois Mountains, SE Missouri. Journal of Geology 104, 55-70.

Viiding, H. 1976. Ob interpretatsii dannykh mineralogicheskogo analiza. In: Norbutas, V. (ed.) Metodika i interpretatsija rezul'tatov mineralogicheskikh i geohimicheskikh issledovanij. Vilnius: Mokslas, 53-59. (in Russian; translated title: Interpretation techniques of mineralogical and geochemical data)

Viiding, H. \& Konsa, M. 1976. Uchet dannykh po tipomorfnym raznovidnostjam mineralov terrigennykh otlozhenij. In: Narbutas, V. (ed.) Metodika i interpretatsija rezul'tatov mineralogicheskikh i geohimicheskikh issledovanij. Vilnius: Mokslas, 60-67. (in Russian; translated title: Interpretation of mineral typologies of clastic sediments) 